\title{
The role and importance of Non-Profit Organizations
}

\author{
Nicoleta Ciucescu,’Vasile Alecsandri" University of Bacau, Romania
}

\begin{abstract}
In a complex and challenging background of the whole country, and the NGO sector also, the non-profit organizations are established with the aim of providing public services to communities where they operate, making them as an intermediary between citizens and authorities.

In any democratic society these organizations are meant to serve different types of needs and interests of the community, from both a strategic perspective and ethics, that those which are not covered by other categories of institutions and organizations, mean time providing a framework for civic participation, where citizens may participate to the public life.
\end{abstract}

\section{Keywords}

institutions, interests, public life, flexibility, public services

\section{Introduction}

In the last years the NGOs in Romania have regained their identity and had a major impact on the modernization of society. They have created, defined and promoted a self-image, forming a group and also having a place and a role in the Romanian civil society. Thus, NGOs have recently taken over, amid a crisis of state resources, functions and roles which in the past were the exclusive power of government, becoming a very important factor in promoting the values of democracy and the new relationships established between state and society.

NGOs are characterized by functional dynamics of methods because their running is directly influenced by the community needs and the specific ways of interacting with the civil society.

\section{The Role Of Non-Profit Organizations In Today’s Society}

Regardless of how NGOs are called - "non-commercial organizations", "non-profit organizations", "NGOs", "associative commercial sector, "civil society", "the third sector", "non-profit association", "organizations without lucrative purpose" etc. - all have a single definition. They are willing parties, in their own right, established by the free will of the citizens who are associated on common career interests and/or other interests aiming to achieve shared civil, economic, social and cultural rights and not obtaining profits.

The mobility of non-governmental organizations mirrors the community capacity to respond rapidly to its needs. NGOs direct to the community the resources that the government does not have or can not collect.

Also, the lines of actions analysis of nongovernmental organizations may be relevant for the problems solving by the public administration. The NGOs play an important role in highlighting issues that might pass unnoticed by the public authorities and in 
helping them to solve problems by using their human resources, local data and their organizational capacity, even monitoring their activities.

NGOs can offer tangible solutions to the community problems more efficiently and involving less costs than the public administrations in areas such as social work or management of social welfare institutions.

The main ways of influencing the NGO sector are:

1. Encouraging the officials and the government agencies to accept some variants of solving the problems, which are successfully used in the sector.

2. educating and informing the public of the rights provided by law and the increase of their awareness of these aspects.

3. active participation in adjusting the official programs to the needs of the community, expressing the public opinion and taking into account the specific conditions of the area

4. co-operation with official agencies.

5. influencing the local development policies of national and international institutions.

6. supporting the governments and donors to develop more effective development strategy through strengthening the institutions, increasing the level of professional qualification of their personnel, training their staff in order to acquire a good management capacity.

NGOs are sometimes perceived as "alternatives" to the solutions proposed by the public administration. The population of a community can not choose the development policy developed by the government or by the NGOs because NGOs can not launch such an offer. It is unlikely that the NGOs can solve the problems of the local communities by their own efforts, the lack of resources being the main cause.

The NGOs may find optimal ways and solutions for solving social problems but these ones can be completed only if they have an impact on the development of the whole community. The public administrations and NGOs can not provide competitive solutions but complementary solutions which can lead to the co-operation between the two bodies.

\section{Functions, Principles and Policies}

Non-governmental organizations have often demonstrated their effectiveness in identifying and solving the community social problems, in attracting and enhancing the value of human and financial resources, in estimating the efficiency degree of the public policies:

- raising the quality standards of the public services

- more efficient management of the public assets

- increased profits of the public services;

- better preservation of the public property

- optimizing the administrative costs

In the context of an increasing demand for public services there is the need of more diversified services than those provided by the government. Therefore, the public authorities have to choose between improving and diversifying their offer or contracting these services.

If we keep in mind the other countries experience we can say that the contracting of these services is more profitable for economic efficiency reasons. In the context of constraints related to their redistributive function and the politic responsibilities regarding the management of public budget, which is limited, NGOs may contract public services.

Contracting services by NGOs would be more beneficial taking into account the nonprofit distribution feature which generates in the case of non-profit contracts, more 
confidence from the beneficiaries and contractors than in the case of profit-oriented contracts. These services contracting can be made by companies, NGOs or by both.

In this situation the main object of the services contract between the public authorities and the NGOs will be an objective set by the authorities and the service provider (NGO) will carry out that goal, considered by the authority being of public interest. The services contract between the public authorities and NGO is the agreement by which the public authority orders the achievement of an objective or service which it will pay for and the NGO binds oneself to perform the object of the contract.

The concession contract is the legal framework of public services contracting from Romanian public authorities. The Government Decision 1228/1990 makes no particular references to the concession of services to the nonprofit sector neither for the purposes of its exemption from such activity, nor for the purpose of encouraging the purchase of services by this sector from the public authorities.

The nongovernmental organizations also have other roles:

- Counterweight to state power and the private sector, such as the consumer protection associations which educate and protect the citizens (consumers) in their relationship with commercial entities.

- They offer the framework for citizen participation to the community life despite of two major difficulties faced when trying to increase the involvement of mass authentic government policy, namely:

- decentralization of decision areas at the state level;

- the absence of the skills and values needed for the participation.

Participation in the activities of NGOs requires member involvement in decision making processes which develop their appropriate skills and the ability to exercise the role of homo politicus.

- In the context where the companies, state institutions and the public administration officials fail to identify and meet a whole wide variety of needs and interests in society and provide poor public services, the NGOs contribute also to provide public services and goods. They are not restricted to the profitability criterion (as companies) and at the same time show greater responsiveness and creativity in covering social needs. Sometimes, even non-governmental organizations may face some obstacles carrying out this work, such as those related to collective action mechanisms.

- The provision of better goods and services compared to those provided by the public sector, a less bureaucratic administrative structure and the presence of volunteers are prerequisites for lower costs of production of the goods or services delivered by the NGOs. It should also be noted that non-governmental organizations are oriented toward the customer satisfaction, and not toward the compliance of formal and bureaucratic procedures.

- The NGOs are also facilitators of social integration and political integration and contribute to groups and individuals integration into society. In societies where there is a high degree of ethnic variety, non-governmental organizations participate in promoting diversity, the decrease of ethnic tensions and interethnic dialogue.

- They constitute a framework where the interests and the claims of people can be expressed. Citizens find in NGOs a framework to express their claims. Sometimes the pressures from different groups are changed in consistent approaches to influence public policy.

- NGOs promote the diversity of opinion of citizens and their members, aware of the existence of different views and interests in society, do not hesitate to criticize them.

NGOs provide cheaper and better services because they use volunteers, thereby helping to improve the efficiency and effectiveness of socio-economic activities. In this respect, a comparison can be made: non-governmental organizations place nearly 
free labor in many areas, such as animal welfare, retraining, environmental protection, adult education at distance, information spread, while government officials must pay for these activities.

The NGOs suppose the team work, the transparency and public participation, without which an administration might not get public support for actions they undertake. NGOs have made an important contribution to the reform process, even if the support received from the state was a minimal one and insufficient, compared with its size.

There are multiple contributions of nongovernmental organizations, the most important being mentioned below.

- They have significantly improved public decisions (for example: correcting and improving various bills and other regulations);

- They have actively participated in the process of education reform;

- They were the basis for success in international mediation. They contributed to increasing the positive public image of their country, promoting international cooperation.

- They have effectively managing the transfer of know-how;

- They have taken over almost entirely the policies of child protection and other concrete activities related to this domain;

- They represent the indigenous culture and initiate the development of cultural diversity, preparing the ground for an advantageous interethnic dialogue, for tolerance and cooperation with national minorities.

The way that organizations act illustrate a model to approach the social issues. It is not necessarily the only one or the best, but certainly it is very efficient in terms of investment - effect report. The activities of NGOs do not replace the public administration activities and NGOs do not carry out the objectives of public administration.

NGOs are rather reflecting a way of action which is complementary to the responsibilities of the community administration and are not an appropriate alternative of the public administration.

An important function of the nonprofit sector is to support the strengthening of social systems, to give to the citizens the possibility to influence public policies, to criticize and to monitor the government policy. Public policies are plans, principles, laws and actions that are developed by decision makers aiming to solve a problem in society, to resist a threat or to achieve an objective. The public policy refer to the government or parliament decisions to address development issues that can have effects on the entire society. They also refer to all measures of a government action program aiming to induce beneficial changes for the society or for a certain part of the society.

Both NGOs and public authorities should provide direct benefits to citizens and promote the development during the developing and the implementing the public policies.

If we consider the decision maker and the coverage area classification criteria, the public policies that NGOs attempt to influence can be classified as: national, regional or local and belonging to domestic institutions. The public policies can be classified into four categories, keeping in mind the roles outlined above :

- Distributive policies, that authorize something or give an advantage (the ability to build something, etc.);

- Redistributive policies, which specify the criteria of granting or prohibiting rights, benefits, incomes, etc.;

- Policies aiming to establish behavior rules (e.g. rule of the road);

- Constitutive policies, which mention rules to establish other rules (Code of Criminal Procedure).

The actors who may be involved in influencing the public policies may be of several kind: 
- Political actors, internal actors (political parties, pressure groups) and international actors (European Council, European Union, World Bank)

- apolitical actors, formally constituted organizations (NGOs, unions, etc.) and informal networks (groups of influence).

We also should also talk about the means used to influence successfully the public policies:

1. Providing expert advice on a specific problem that local and central authorities wish to solve, for example, Romanian Association of Humanitarian Law and Human Rights Association in Romania - Helsinki Committee have contributed to the completion of the Law on Refugees in Romania.

2. Information campaigns; this method is based on publication or broadcasting on radio or TV of some messages that aim to make the community aware of an issue which has to be solved. This means of influencing public policy is based on effective cooperation with the media.

Serious errors, the distorting of the message, the difficulty of communication, the need of an accurate information are just some of the elements of the organizational relationship with the Romanian medias. The relation between public authorities, NGOs which implement public policies and medias should be governed by professional standards. Journalists should always apply the journalism rules in writing a press release, making a database or monitoring.

3. Public policy research, the study of public policies by the political research institutes, called also "think thanks", plays an increasing role in influencing public policies.

They inform and educate citizens and play an advisory role for parliamentarians, members of the Government, local governments.

4. Coalition building (temporary or permanently) to develop public campaigns of important cause advocacy (lobby and advocacy campaigns).

\section{Conclusions}

NGOs play a major role in identifying social problems, in finding solutions, and even in achieving social objectives in a variety of areas that public administrations can not cover efficiently or not at all.

These NGOs can be partially or fully committed to do some functions of public administration, achieving the objectives imposed by it and without replacing the administration.

NGOs and public administration are complementary and NGOs do not represent an alternative to the public administration.

\section{References}

1. Cole, G.A. (1988), Personnel Management. Theory and Practice, D.P. Publications Ltd, London

2. Criuimins, J.C. şi Keil, M. (1983), Enterprise in the Non-Profit Sector, Rockefeller Brothers Fund, New York

3. Drucker, F. P. (1992), Managing the Non-Profit Organization. Principles and Practices, Flarper Business, New York

4. Salamon, L. şi Helmut A. (1994), The Emerging Sector. An Overview, The Johns Hopkins University, Institute for Policy Studies, Baltimore

5. Schmid, H. şi D. Bargal (1988), Patterns of management and organizational effectiveness among executives and program directors in community services organizations, Hebrew University of Ierusalim, Paul Baerwald School of Social Work, Jerusalim 
6. Vlăsceanu, M. (1995), Politica socială şi sectorul nonprofit, în : Elena Zamfir şi Cătălin Zamfir (coord.), Politici sociale. România în context european, Editura Alternative, Bucureşti 7. *** Dimensiuni ale Sectorului Neguvernamental din România, (1997) Fundaţia pentru Dezvoltarea Societăţii Civile, Seria: Studii asupra Sectorului Nonprofit, numărul 3

8. *** Modelul Românesc de Evoluţie al Fenomenului Asociativ Voluntar,( 1997) FDSC, Seria: Studii şi Cercetări asupra Sectorului Nonprofit, numărul 4

9. *** Ghid juridic şi practic pentru organizaţiile neguvernamentale cu scop nelucrativ (1996) SIC Press Group, Bucureşti 